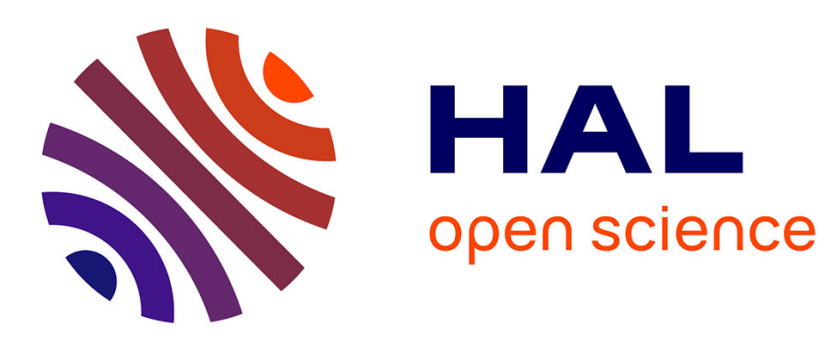

\title{
Improving Post-Cardiac Arrest Cerebral Perfusion Pressure by Elevating the Head and Thorax
}

Hélène Duhem

\section{To cite this version:}

Hélène Duhem. Improving Post-Cardiac Arrest Cerebral Perfusion Pressure by Elevating the Head and Thorax. Human health and pathology. 2020. dumas-03332463

\section{HAL Id: dumas-03332463 https://dumas.ccsd.cnrs.fr/dumas-03332463}

Submitted on 30 Sep 2021

HAL is a multi-disciplinary open access archive for the deposit and dissemination of scientific research documents, whether they are published or not. The documents may come from teaching and research institutions in France or abroad, or from public or private research centers.
L'archive ouverte pluridisciplinaire HAL, est destinée au dépôt et à la diffusion de documents scientifiques de niveau recherche, publiés ou non, émanant des établissements d'enseignement et de recherche français ou étrangers, des laboratoires publics ou privés. 


\section{UCA \\ FACULTÉ \\ DE MÉDECINE Uriversitite Alpes}

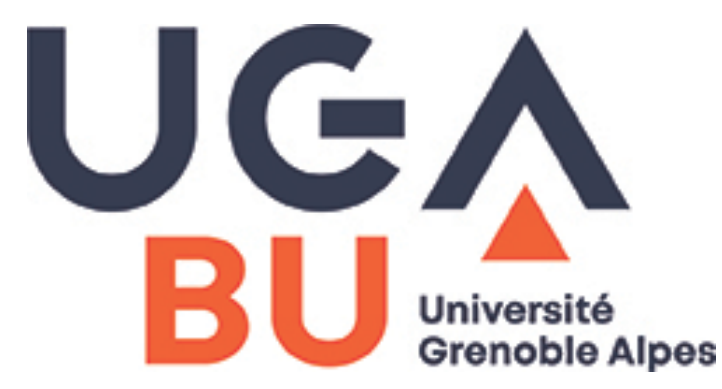

\section{AVERTISSEMENT}

Ce document est le fruit d'un long travail approuvé par le jury de soutenance.

La propriété intellectuelle du document reste entièrement celle du ou des auteurs. Les utilisateurs doivent respecter le droit d'auteur selon la législation en vigueur, et sont soumis aux règles habituelles du bon usage, comme pour les publications sur papier : respect des travaux originaux, citation, interdiction du pillage intellectuel, etc.

Il est mis à disposition de toute personne intéressée par l'intermédiaire de l'archive ouverte DUMAS (Dépôt Universitaire de Mémoires Après Soutenance).

Si vous désirez contacter son ou ses auteurs, nous vous invitons à consulter la page de DUMAS présentant le document. Si l'auteur l'a autorisé, son adresse mail apparaîtra lorsque vous cliquerez sur le bouton «Détails » (à droite du nom).

Dans le cas contraire, vous pouvez consulter en ligne les annuaires de l'ordre des médecins, des pharmaciens et des sages-femmes.

Contact à la Bibliothèque universitaire de Médecine Pharmacie de Grenoble : bump-theses@univ-grenoble-alpes.fr 


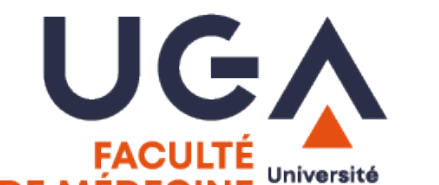

DE MÉDECINE Grenoble Alpes

Année : 2020

\title{
L'ÉLÉVATION DE LA TÊTE ET DU TRONC AMÉLIORE LA PRESSION DE PERFUSION CÉRÉBRALE EN POST-ARRÊT CARDIAQUE
}

\author{
THÈSE \\ PRÉSENTÉE POUR L'OBTENTION DU TITRE DE DOCTEUR EN MÉDECINE \\ DIPLÔME D’ÉTAT
}

Hélène DUHEM

[Données à caractère personnel]

THÈSE SOUTENUE PUBLIQUEMENT À LA FACULTÉ DE MÉDECINE DE GRENOBLE

Le : $21 / 09 / 2020$

DEVANT LE JURY COMPOSÉ DE

Président du jury :

M. le Professeur Gérald VANZETTO

$\underline{\text { Membres : }}$

M. le Professeur Pierre BOUZAT

M. le Professeur Guillaume DEBATY (Directeur de thèse)

M. le Docteur Stéphane TANGUY

M. le Docteur Damien VIGLINO

L'UFR de Médecine de Grenoble n'entend donner aucune approbation ni improbation aux opinions émises dans les thèses; ces opinions sont considérées comme propres à leurs auteurs. 
UFR de

Médecine

UNIVERSITÉ

Grenoble

Alpes

Doyen de la Faculté : Pr. Patrice MORAND

Année 2019-2020

ENSEIGNANTS DE L'UFR DE MEDECINE

\begin{tabular}{|c|c|c|}
\hline CORPS & NOM-PRENOM & Discipline universitaire \\
\hline PU-PH & ALBALADEJO Pierre & Anesthésiologie-réanimation et médecine péri-opératoire \\
\hline PU-PH & APTEL Florent & Ophtalmologie \\
\hline PU-PH & ARVIEUX-BARTHELEMY Catherine & Chirurgie viscérale et digestive \\
\hline PU-PH & BAILLET Athan & Rhumatologie \\
\hline PU-PH & BARONE-ROCHETTE Gilles & Cardiologie \\
\hline PU-PH & BAYAT Sam & Physiologie \\
\hline MCF Ass.MG & BENDAMENE Farouk & Médecine Générale \\
\hline PU-PH & BENHAMOU Pierre Yves & Endocrinologie, diabète et maladies métaboliques \\
\hline PU-PH & BERGER François & Biologie cellulaire \\
\hline MCU-PH & BIDART-COUTTON Marie & Biologie cellulaire \\
\hline PU-PH & BLAISE Sophie & Chirurgie vasculaire; médecine vasculaire \\
\hline MCU-PH & BOISSET Sandrine & Bactériologie-virologie \\
\hline PU-PH & BOLLA Michel & Cancérologie-Radiothérapie \\
\hline PU-PH & BONAZ Bruno & Gastroentérologie, hépatologie, addictologie \\
\hline PU-PH & BONNETERRE Vincent & Médecine et santé au travail \\
\hline PU-PH & BOREL Anne-Laure & Nutrition \\
\hline PU-PH & BOSSON Jean-Luc & Biostatistiques, informatique médicale et technologies de communication \\
\hline MCU-PH & BOTTARI Serge & Biologie cellulaire \\
\hline PR Ass.MG & BOUCHAUD Jacques & Médecine Générale \\
\hline PU-PH & BOUGEROL Thierry & Psychiatrie d'adultes \\
\hline PU-PH & BOUILLET Laurence & Médecine interne \\
\hline MCU-PH & BOUSSAT Bastien & Epidémiologie, économie de la santé et prévention \\
\hline PU-PH & BOUZAT Pierre & Anesthésiologie-réanimation et médecine péri-opératoire \\
\hline PU-PH & BRAMBILLA Christian & Pneumologie \\
\hline PU-PH & BRAMBILLA Elisabeth & Anatomie et cytologie pathologiques \\
\hline MCU-PH & BRENIER-PINCHART Marie Pierre & Parasitologie et mycologie \\
\hline PU-PH & BRICAULT Ivan & Radiologie et imagerie médicale \\
\hline PU-PH & BRICHON Pierre-Yves & Chirurgie thoracique et cardiovasculaire \\
\hline MCU-PH & BRIOT Raphaël & Thérapeutique-médecine de la douleur \\
\hline MCU-PH & BROUILLET Sophie & Biologie et médecine du développement et de la reproduction \\
\hline PU-PH & CAHN Jean-Yves & Hématologie \\
\hline PU-PH & CARPENTIER Patrick & Chirurgie vasculaire, médecine vasculaire \\
\hline PR Ass.MG & CARRILLO Yannick & Médecine Générale \\
\hline PU-PH & CESBRON Jean-Yves & Immunologie \\
\hline PU-PH & CHABARDES Stephan & Neurochirurgie \\
\hline PU-PH & CHABRE Olivier & Endocrinologie, diabète et maladies métaboliques \\
\hline PU-PH & CHAFFANJON Philippe & Anatomie \\
\hline
\end{tabular}




\begin{tabular}{|c|c|c|}
\hline CORPS & NOM-PRENOM & Discipline universitaire \\
\hline PU-PH & CHARLES Julie & Dermato-vénéréologie \\
\hline MCF Ass.MG & CHAUVET Marion & Médecine Générale \\
\hline PU-PH & CHAVANON Olivier & Chirurgie thoracique et cardio- vasculaire \\
\hline PU-PH & CHIQUET Christophe & Ophtalmologie \\
\hline PU-PH & CHIRICA Mircea & Chirurgie viscérale et digestive \\
\hline PU-PH & CINQUIN Philippe & Biostatistiques, informatique médicale et technologies de communication \\
\hline MCU-PH & CLAVARINO Giovanna & Immunologie \\
\hline PU-PH & COHEN Olivier & Histologie, embryologie et cytogénétique \\
\hline PU-PH & COURVOISIER Aurélien & Chirurgie infantile \\
\hline PU-PH & COUTTON Charles & Génétique \\
\hline PU-PH & COUTURIER Pascal & Gériatrie et biologie du vieillissement \\
\hline PU-PH & CRACOWSKI Jean-Luc & Pharmacologie fondamentale, pharmacologie clinique \\
\hline PU-PH & CURE Hervé & Cancérologie \\
\hline PU-PH & DEBATY Guillaume & Médecine d'Urgence \\
\hline PU-PH & DEBILLON Thierry & Pédiatrie \\
\hline PU-PH & DECAENS Thomas & Gastro-entérologie, Hépatologie \\
\hline PU-PH & DEMATTEIS Maurice & Addictologie \\
\hline PU-PH & DEMONGEOT Jacques & Biostatistiques, informatique médicale et technologies de communication \\
\hline MCU-PH & DERANSART Colin & Physiologie \\
\hline PU-PH & DESCOTES Jean-Luc & Urologie \\
\hline PU-PH & DETANTE Olivier & Neurologie \\
\hline MCU-PH & DIETERICH Klaus & Génétique \\
\hline MCU-PH & DOUTRELEAU Stéphane & Physiologie \\
\hline MCU-PH & DUMESTRE-PERARD Chantal & Immunologie \\
\hline PU-PH & EPAULARD Olivier & Maladies infectieuses; Maladies tropicales \\
\hline PU-PH & ESTEVE François & Biophysique et médecine nucléaire \\
\hline MCU-PH & EYSSERIC Hélène & Médecine légale et droit de la santé \\
\hline PU-PH & FAUCHERON Jean-Luc & Chirurgie viscérale et digestive \\
\hline MCU-PH & FAURE Julien & Biochimie et biologie moléculaire \\
\hline PU-PH & FERRETTI Gilbert & Radiologie et imagerie médicale \\
\hline PU-PH & FEUERSTEIN Claude & Physiologie \\
\hline PU-PH & FONTAINE Éric & Nutrition \\
\hline PU-PH & FRANCOIS Patrice & Epidémiologie, économie de la santé et prévention \\
\hline MCU-MG & GABOREAU Yoann & Médecine Générale \\
\hline PU-PH & GARBAN Frédéric & Hématologie ; Transfusion \\
\hline PU-PH & GAUDIN Philippe & Rhumatologie \\
\hline PU-PH & GAVAZZI Gaétan & Gériatrie et biologie du vieillissement \\
\hline PU-PH & GAY Emmanuel & Neurochirurgie \\
\hline MCU-PH & GILLOIS Pierre & Biostatistiques, informatique médicale et technologies de communication \\
\hline PU-PH & GIOT Jean-Philippe & Chirurgie plastique, reconstructrice et esthétique \\
\hline MCU-PH & GRAND Sylvie & Radiologie et imagerie médicale \\
\hline PU-PH & GRIFFET Jacques & Chirurgie infantile \\
\hline MCU-PH & GUZUN Rita & Nutrition \\
\hline PU-PH & HAINAUT Pierre & Biochimie et biologie moléculaire \\
\hline PU-PH & HALIMI Serge & Nutrition \\
\hline PU-PH & HENNEBICQ Sylviane & Biologie et médecine du développement et de la reproduction \\
\hline PU-PH & HOFFMANN Pascale & Gynécologie-obstétrique \\
\hline
\end{tabular}




\begin{tabular}{|c|c|c|}
\hline CORPS & NOM-PRENOM & Discipline universitaire \\
\hline PU-PH & HOMMEL Marc & Neurologie \\
\hline PU-MG & IMBERT Patrick & Médecine Générale \\
\hline PU-PH & JOUK Pierre-Simon & Génétique \\
\hline PU-PH & KAHANE Philippe & Physiologie \\
\hline MCU-PH & KASTLER Adrian & Radiologie et imagerie médicale \\
\hline PU-PH & KRAINIK Alexandre & Radiologie et imagerie médicale \\
\hline PU-PH & LABARERE José & Epidémiologie, économie de la santé et prévention \\
\hline MCU-PH & LABLANCHE Sandrine & Endocrinologie, diabète et maladies métaboliques \\
\hline MCU-PH & LANDELLE Caroline & Bactériologie - virologie ; Hygiène hospitalière \\
\hline PU-PH & LANTUEJOUL Sylvie & Anatomie et cytologie pathologiques \\
\hline MCU-PH & LARDY Bernard & Biochimie et biologie moléculaire \\
\hline MCU - PH & LE GOUELLEC Audrey & Biochimie et biologie moléculaire \\
\hline PU-PH & LECCIA Marie-Thérèse & Dermato-vénéréologie \\
\hline MCF Ass.MG & LEDOUX Jean-Nicolas & Médecine Générale \\
\hline PU-PH & LEROY Vincent & Gastroentérologie ; hépatologie ; addictologie \\
\hline PU-PH & LETOUBLON Christian & Chirurgie viscérale et digestive \\
\hline PU-PH & LEVY Patrick & Physiologie \\
\hline PU-PH & LONG Jean-Alexandre & Urologie \\
\hline MCU-PH & LUPO Julien & Bactériologie-virologie \\
\hline PU-PH & MAGNE Jean-Luc & Chirurgie vasculaire ; Médecine vasculaire \\
\hline MCU-PH & MAIGNAN Maxime & Médecine d'urgence \\
\hline PU-PH & MAITRE Anne & Médecine et santé au travail \\
\hline MCU-PH & MALLARET Marie-Reine & Hygiène hospitalière \\
\hline PU-PH & MALLION Jean-Michel & Cardiologie \\
\hline MCU-PH & MARLU Raphaël & Hématologie ; Transfusion \\
\hline MCU-PH & MAUBON Danièle & Parasitologie et mycologie \\
\hline PU-PH & MAURIN Max & Bactériologie-virologie \\
\hline MCU-PH & MC LEER Anne & Histologie, embryologie et cytogénétique \\
\hline MCU-PH & MONDET Julie & Histologie, embryologie et cytogénétique \\
\hline PU-PH & MORAND Patrice & Bactériologie-virologie \\
\hline PU-PH & MOREAU-GAUDRY Alexandre & Biostatistiques, informatique médicale et technologies de communication \\
\hline PU-PH & MORO Elena & Neurologie \\
\hline PU-PH & MORO-SIBILOT Denis & Pneumologie \\
\hline MCU-PH & MORTAMET Guillaume & Pédiatrie \\
\hline PU-PH & MOUSSEAU Mireille & Cancérologie \\
\hline PU-PH & MOUTET François & Chirurgie plastique, reconstructrice et esthétique ; brûlologie \\
\hline MCF Ass.MG & ODDOU Christel & Médecine Générale \\
\hline MCU-PH & PACLET Marie-Hélène & Biochimie et biologie moléculaire \\
\hline PU-PH & PAILHE Régis & Chirurgie orthopédique et traumatologie \\
\hline PU-PH & PALOMBI Olivier & Anatomie \\
\hline PU-PH & PARK Sophie & Hématologie ; Transfusion \\
\hline PU-PH & PASSAGGIA Jean-Guy & Anatomie \\
\hline PR Ass.MG & PAUMIER-DESBRIERES Françoise & Médecine Générale \\
\hline PU-PH & PAYEN DE LA GARANDERIE Jean-François & Anesthésiologie-réanimation et médecine péri-opératoire \\
\hline MCU-PH & PAYSANT François & Médecine légale et droit de la santé \\
\hline MCU-PH & PELLETIER Laurent & Biologie cellulaire \\
\hline PU-PH & PELLOUX Hervé & Parasitologie et mycologie \\
\hline
\end{tabular}




\begin{tabular}{|c|c|c|}
\hline CORPS & NOM-PRENOM & Discipline universitaire \\
\hline PU-PH & PEPIN Jean-Louis & Physiologie \\
\hline PU-PH & PERENNOU Dominique & Médecine physique et de réadaptation \\
\hline PU-PH & PERNOD Gilles & Médecine vasculaire \\
\hline PU-PH & PIOLAT Christian & Chirurgie infantile \\
\hline PU-PH & PISON Christophe & Pneumologie \\
\hline PU-PH & PLANTAZ Dominique & Pédiatrie \\
\hline PU-PH & POIGNARD Pascal & Bactériologie-virologie \\
\hline PU-PH & POLACK Benoît & Hématologie \\
\hline PU-PH & POLOSAN Mircea & Psychiatrie d'adultes \\
\hline PU-PH & RAMBEAUD Jean-Jacques & Urologie \\
\hline PU-PH & RAY Pierre & Biologie et médecine du développement et de la reproduction \\
\hline MCU-PH & RENDU John & Biochimie et biologie moléculaire \\
\hline MCU-PH & RIALLE Vincent & Biostatistiques, informatique médicale et technologies de communication \\
\hline PU-PH & RIETHMULLER Didier & Gynécologie-obstétrique ; gynécologie médicale \\
\hline PU-PH & RIGHINI Christian & Oto-rhino-laryngologie \\
\hline PU-PH & ROMANET Jean Paul & Ophtalmologie \\
\hline PU-PH & ROSTAING Lionel & Néphrologie \\
\hline MCU-PH & ROUSTIT Matthieu & Pharmacologie fondamentale; pharmacologie clinique ; addictologie \\
\hline MCU-PH & ROUX-BUISSON Nathalie & Biochimie et biologie moléculaire \\
\hline MCF Ass.MG & ROYER DE VERICOURT Guillaume & Médecine Générale \\
\hline MCU-PH & RUBIO Amandine & Pédiatrie \\
\hline PU-PH & SARAGAGLIA Dominique & Chirurgie orthopédique et traumatologie \\
\hline MCU-PH & SATRE Véronique & Génétique \\
\hline PU-PH & SAUDOU Frédéric & Biologie cellulaire \\
\hline PU-PH & SCHMERBER Sébastien & Oto-rhino-laryngologie \\
\hline PU-PH & SCHWEBEL Carole & Médecine intensive-réanimation \\
\hline PU-PH & SCOLAN Virginie & Médecine légale et droit de la santé \\
\hline MCU-PH & SEIGNEURIN Arnaud & Epidémiologie, économie de la santé et prévention \\
\hline PU-PH & STAHL Jean-Paul & Maladies infectieuses ; Maladies tropicales \\
\hline PU-PH & STANKE Françoise & Pharmacologie fondamentale \\
\hline MCU-PH & STASIA Marie-José & Biochimie et biologie moléculaire \\
\hline PU-PH & STURM Nathalie & Anatomie et cytologie pathologiques \\
\hline PU-PH & TAMISIER Renaud & Physiologie \\
\hline PU-PH & TERZI Nicolas & Médecine intensive-réanimation \\
\hline MCU-PH & TOFFART Anne-Claire & Pneumologie \\
\hline PU-PH & TONETTI Jérôme & Chirurgie orthopédique et traumatologie \\
\hline PU-PH & TOUSSAINT Bertrand & Biochimie et biologie moléculaire \\
\hline PU-PH & VANZETTO Gérald & Cardiologie \\
\hline PU-PH & VUILLEZ Jean-Philippe & Biophysique et médecine nucléaire \\
\hline PU-PH & WEIL Georges & Epidémiologie, économie de la santé et prévention \\
\hline PU-PH & ZAOUI Philippe & Néphrologie \\
\hline PU-PH & ZARSKI Jean-Pierre & Gastroentérologie ; hépatologie ; addictologie \\
\hline
\end{tabular}

PU-PH : Professeur des Universités - Praticiens Hospitaliers

MCU-PH : Maître de Conférences des Universités - Praticiens Hospitaliers

PU-MG : Professeur des Universités de Médecine Générale

MCU-MG : Maître de Conférences des Universités de Médecine Générale

PR Ass.MG : Professeur des Universités Associé de Médecine Générale

MCF Ass.MG : Maitre de Conférences Associé de Médecine Générale 


\section{REMERCIEMENTS}

\section{Aux membres du Jury,}

Au Pr Gérald Vanzetto, j'ai eu l'honneur de vous rencontrer lors de mon projet de Master 2, vous avez accepté de présider ce jury de thèse, soyez assuré de mon profond respect et de ma sincère gratitude.

Au Pr Pierre Bouzat, vous me faites l'honneur de participer à mon jury de thèse et d'apporter votre expertise de réanimateur à l'évaluation de ce travail. Veuillez trouver ici l'expression de mes sincères remerciements.

Au Dr Stéphane Tanguy, je tenais à ce que tu fasses partie de ce jury et je te remercie d'avoir accepté de juger ce travail. Merci de l'aide que tu m'as apporté lors de mes travaux précédents et merci d'avoir partagé avec moi tes compétences en physiologie et en recherche. Travailler avec toi est un véritable plaisir, j'espère que nous aurons à nouveau l'occasion de collaborer.

Au Dr Damien Viglino, merci d'avoir accepté de faire partie de ce jury, merci pour ton aide sur chacun de mes projets et pour ta bienveillance. J'envisage avec joie la perspective de travailler de nouveau avec toi, en recherche et aux urgences.

Au Pr Guillaume Debaty, merci de la confiance que tu m'accordes depuis 2 ans. La passion de la recherche qui t'anime est pour moi une réelle inspiration. Je te remercie des opportunités incroyables que tu m'offres et du temps que tu consacres à ma formation. 


\section{TITLE :}

Improving Post-Cardiac Arrest Cerebral Perfusion Pressure by Elevating the Head and

\section{Thorax}

\section{AUTHORS :}

Hélène Duhem ${ }^{\mathrm{a}}$, Johanna C Moore ${ }^{\mathrm{b}, \mathrm{c}}$, Carolina Rojas-Salvador ${ }^{\mathrm{b}}$, Bayert Salverda ${ }^{\mathrm{c}}$, Michael Lick $^{\mathrm{c}}$, Paul Pepe ${ }^{\mathrm{d}, \mathrm{e}}$, Jose Labarere ${ }^{\mathrm{a}}$, Guillaume Debaty ${ }^{\mathrm{a}}$, Keith G Lurie ${ }^{\mathrm{b}, \mathrm{c}}$

a University Grenoble Alps/CNRS/CHU de Grenoble Alpes/TIMC-IMAG UMR 5525, Grenoble, France

${ }^{\mathrm{b}}$ Department of Emergency Medicine, Hennepin Healthcare, Minneapolis, MN, USA.

${ }^{c}$ Hennepin Healthcare Research Institute, Minneapolis, MN, USA.

d Dallas County Fire Rescue, Dallas, TX, United States

e Palm Beach County Fire Rescue, West Palm Beach, FL and Broward Sheriff's Office, Fire Rescue Department Fort Lauderdale, FL, United States

\section{KEYWORDS}

Active compression-decompression CPR, Cardiac arrest, Cardiopulmonary Resuscitation, Return of spontaneous circulation, Cerebral perfusion pressure, Head Up CPR, Posture 


\section{LIST OF ABBREVIATIONS}

ABG: Arterial blood gas

ACD: Active compression decompression

AoP: Aortic blood pressure

BLS: Basic life support

CA: Cardiac arrest

C-CPR: Conventional CPR

CED: Customized head and thorax elevation device

CerPP: Cerebral perfusion pressure

CorPP: Coronary perfusion pressure

CPR: Cardiopulmonary resuscitation

EHT: Elevation of the head and thorax

$\mathrm{EtCO}_{2}$ : End tidal carbon dioxide

ETT: Endotracheal tube

HHRI: Hennepin Healthcare Research Institute

HUP: Highest CED position

ICP: Intracranial pressure

ITD: Impedance threshold device

ITP: Intrathoracic pressure

MAP: Mean aortic pressure

RAP: Right atrial pressure

ROSC: Return of spontaneous circulation

rSO2: Regional cerebral oximetry

SO2: Transcutaneous oxygen saturation

VF: Ventricular fibrillation 


\section{RÉSUMÉ}

Objectif : L'objectif de cette étude était de déterminer si la tête et le tronc doivent rester en position surélevée après le retour d'une activité circulatoire spontanée (RACS) dans un modèle porcin.

Méthode : Nous avons analysé les données originales de deux études contrôlées randomisées. Dans l'étude A, des cochons femelles de 40kg ont été anesthésiés et positionnés en décubitus dorsal, à plat. Après 7,75 minutes de fibrillation ventriculaire (FV) non traitée, les cochons ont été positionnés au niveau le plus bas sur un dispositif automatisé d'élévation de la tête et du tronc. Après 8 minutes de FV non traitée, une réanimation cardiopulmonaire (RCP) avec compression décompression active et valve d'impédance inspiratoire a été réalisée pendant 2 minutes. Les animaux ont été progressivement surélevés au niveau le plus haut du dispositif (HUP, $35^{\circ}$ d'élévation) et la RCP poursuivie ainsi pendant 30 minutes. Les cochons ont ensuite été défibrillés. Après le RACS, la tête et le tronc ont été maintenus dans la position HUP pendant 10 minutes puis les animaux ont été randomisés en séquences de 5 minutes successives comme suit : $0^{\circ}, 35^{\circ}, 0^{\circ}, 35^{\circ}$ ou inversement. Dans l'étude $\mathrm{B}$, après 6 minutes de FV non traitée, une RCP conventionnelle à plat a été réalisée pendant 6 minutes, après le RACS, les cochons ont été randomisés entre $0^{\circ}$ et $35^{\circ}$ comme dans l'étude A. Le critère de jugement principal était la pression de perfusion cérébrale (CerPP). Une analyse en MANOVA pour mesures répétées a été utilisée. Les données sont présentées comme moyenne \pm écart type et pourcentage d'augmentation par rapport à la position à plat.

Résultats : Comparée à la position à plat, la pression intracrânienne (PIC) était, en position HUP, 9,5 $\pm 1,8 \mathrm{mmHg}(\mathrm{p}<0,001)$ et $8,7 \pm 2,3 \mathrm{mmHg}$ plus basse $(\mathrm{p}<0.001)$, alors que la CerPP était $9,3 \pm 7,0 \mathrm{mmHg}(17 \%)(\mathrm{p}=0,004)$ et $12,5 \pm 5,9(18 \%)(\mathrm{p}=0,001)$ plus élevée, pour les études A et B respectivement. 
Conclusion : Après le RACS, l'élévation de la tête et du tronc était associée avec des pressions de perfusion cérébrale plus élevées et avec des PIC réduites dans un modèle de cochon d'arrêt cardiaque, indépendamment de la durée de la FV et de la méthode de RCP. 


\section{ABSTRACT}

Aim: The optimal head and thorax position after return of spontaneous circulation (ROSC) in cardiac arrest is unknown. The aim of this study was to determine whether head and thorax elevation was beneficial post-ROSC in a porcine model.

Methods: We analysed the original data from two randomized controlled studies. In study A, 40kg anesthetized female pigs were positioned supine and flat. After 7.75 minutes of untreated ventricular fibrillation (VF), pigs were elevated to the lowest customized head and thorax elevation device (CED) position. After 8 minutes of untreated VF, automated active compression decompression (ACD) plus impedance threshold device (ITD) CPR was performed for 2 minutes, then pigs were elevated to the highest CED position (HUP) over 2 minutes. After 30 minutes of HUP ACD+ITD CPR pigs were defibrillated, remained elevated for 10 minutes, and then randomized to 5-minutes epochs of Flat, HUP, Flat, HUP or vice versa. Hemodynamics and cerebral oximetry were measured. In study B, after 6 minutes of untreated VF pigs received 6 minutes of conventional (C) CPR flat, and after ROSC were randomized HUP versus Flat as in Study A. The primary endpoint was cerebral perfusion pressure (CerPP). Multivariate analysis-of-variance (MANOVA) for repeated measures was used. Data were reported as mean $\pm \mathrm{SD}$ and percentage of increase compare to the flat position.

Results: Compared with flat position, intracranial pressure (ICP) values for HUP were $9.5 \pm 1.8$ $\mathrm{mmHg}(\mathrm{p}<0.001)$ and $8.7 \pm 2.3 \mathrm{mmHg}$ lower $(\mathrm{p}<0.001)$, while CerPP values were $9.3 \pm 7.0 \mathrm{mmHg}$ $(17 \%)(\mathrm{p}=0.004)$ and $12.5 \pm 5.9(18 \%)(\mathrm{p}=0.001)$ higher, in studies A and $\mathrm{B}$, respectively.

Conclusion: In a porcine model of cardiac arrest, post-ROSC head and thorax elevation resulted in significantly higher CerPP and lower ICP values, regardless of VF duration or CPR method. 


\section{INTRODUCTION}

Elevation of the head and thorax (EHT) improves clinical outcomes in critically ill patients with traumatic brain injury, heart failure, and respiratory distress [1-5]. In these conditions gravity helps to lower intracranial pressure (ICP) and improve multiple essential physiological processes including oxygenation, transpulmonary flow, and circulation [6-9].

Recent pre-clinical data have shown that gravity-assisted active compression decompression (ACD), cardiopulmonary resuscitation (CPR) with an impedance threshold device (ITD) improves cerebral perfusion pressures and neurologically-intact survival rates after cardiac arrest (CA), especially when using controlled sequential EHT $[10,11]$. Preliminary clinical data have shown that gravity-assisted CPR, used with a bundle of care, is safe and results in improved survival to hospital admission rates [12]. This new approach does not work with CCPR, as forward flow is too limited [12]. However, when used with CPR techniques that augment circulation, EHT harnesses gravity to enhance draining venous blood from the brain, lowers ICP, and improves circulation to the brain, heart and other vital organs. EHT also may protect the brain from abrupt changes in ICP with each chest compression resulting in high pressure arterial and venous waves that simultaneously concuss the brain during CPR [13-17].

While recent evidence supports a clear benefit of gravity-assisted CPR during CA, the optimal position after return of spontaneous circulation (ROSC) remains unknown. Lower ICP and higher CerPP after ROSC may decrease reperfusion injuries in the post CA phase and thereby improve outcome [18].

Building upon recent advances with EHT during CPR, we used a porcine model of CA to test the hypothesis that EHT after ROSC would enhance cerebral perfusion pressure and lower ICP regardless of the duration of cardiac arrest or method of CPR. 


\section{METHODS}

\section{Study ethics}

The study was approved by the Institutional Animal Care and Use Committee of the Hennepin Healthcare Research Institute (HHRI). A certified and licensed HHRI veterinarian assured that animal care and the study protocol were in compliance with the National Research Council 2011 Guidelines for the Care and Use of Laboratory Animals.

\section{Study design and measurements}

We analyzed original data from two experimental studies. Study preparation and surgical techniques were performed as previously described $[11,12,17]$. Female Yorkshire farm pigs weighing $\sim 40 \mathrm{~kg}$ were fasted overnight, received intramuscular ketamine (1000 $\mathrm{mg}$ ) in the holding pen, and then 5\% inhaled isoflurane. Animals were placed on a customized elevation device (CED) (Figure 1), capable of elevating the head and thorax to perform CPR as previously described [19], and then intubated with a $7.5 \mathrm{~mm}$ cuffed endotracheal tube (ETT), connected to an anesthesia machine (Narkomed, North American Drager) and ventilated with a tidal volume of $10 \mathrm{~mL} / \mathrm{kg}$. Isoflurane was continued for anesthesia at $1 \%-2.5 \%$ until 3 minutes prior to induction of ventricular fibrillation (VF). End tidal carbon dioxide $\left(\mathrm{EtCO}_{2}\right)$ and transcutaneous oxygen saturation $\left(\mathrm{SO}_{2}\right)$ were measured with a CO2SMO Plus (Novametrix Systems). Respiratory rate and FiO2 were titrated to keep $\mathrm{SO}_{2}>92 \%$ and $\mathrm{EtCO}_{2}$ between $37-43 \mathrm{mmHg}$. Intravenous access was then obtained and pigs received normal saline during the preparatory phase to maintain a mean right atrial pressure (RAP) between 4 and $7 \mathrm{mmHg}$. 


\section{Figure 1a}

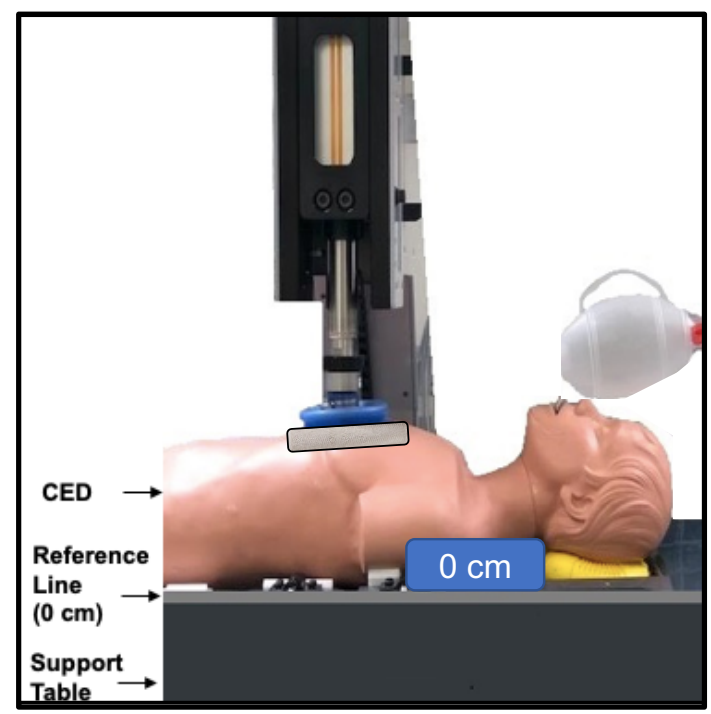

\section{Figure 1b}

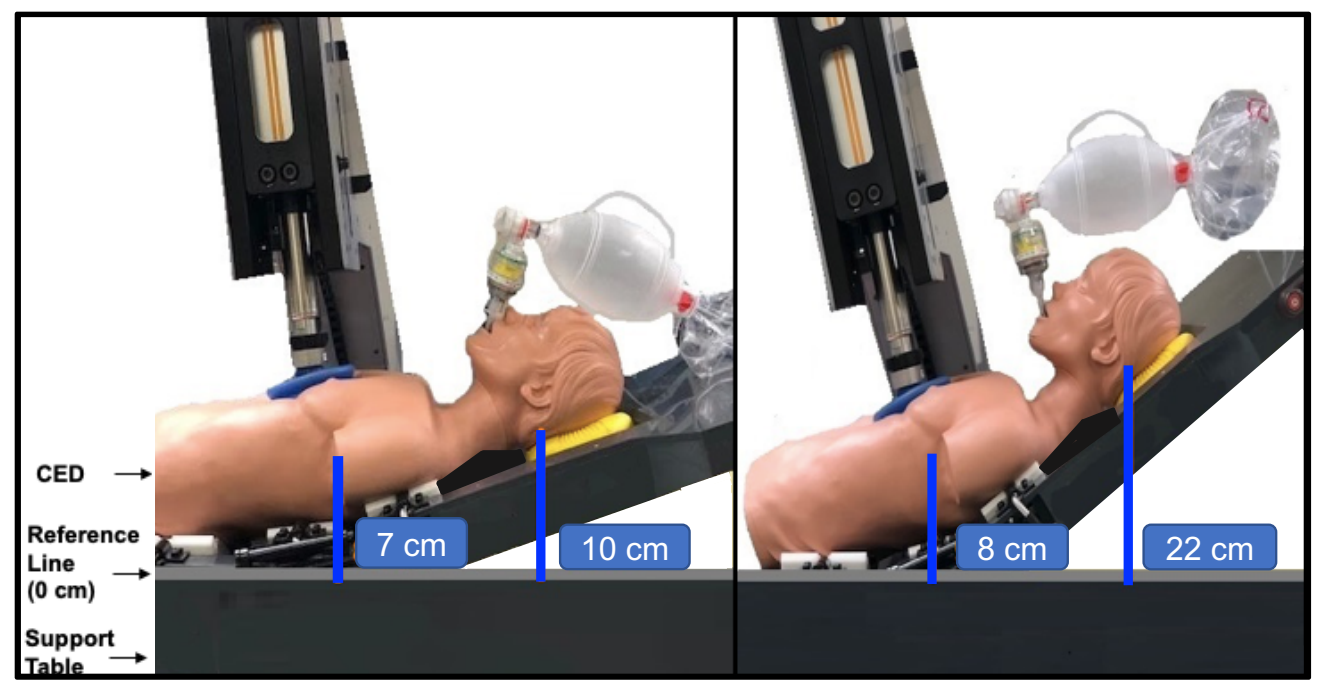

Figure 1: Customized Elevation Device

Figure 1a. Flat position. A washcloth (grey) was placed underneath the suction cup (blue) to allow for full passive chest wall recoil.

Figure 1b. Diagram of the customized elevation device (CED) in the lowest elevation* and highest elevation**

* The heart was elevated $7 \mathrm{~cm}$ and the midbrain $10 \mathrm{~cm}$

** The heart was elevated $8 \mathrm{~cm}$ and the midbrain $22 \mathrm{~cm}$

Animals received a 100 unit/kg bolus of intravenous heparin every hour. Temperature was continuously measured via esophageal probe and maintained between $37-38^{\circ} \mathrm{C}$ during the preparatory phase with a heating pad as needed. Proximal airway pressure was measured at the end of the ETT with a differential pressure transducer (TSD160C, Biopac Systems, Inc). RAP 
and aortic blood pressure (AoP) were measured with micromanometer-tipped catheters (MikroTip Transducer, Millar Instruments) placed in the femoral vein and artery and advanced to the right atrium and thoracic aorta at the level of the diaphragm, respectively. Catheter placement was confirmed with fluoroscopy. An intracranial bolt was placed in a burr hole in the skull to measure ICP with a micromanometer-tipped catheter. It was positioned approximately $5 \mathrm{~mm}$ into cerebral cortex. Regional cerebral oximetry (rSO2) was measured with near infrared sensors (NONIN Medical, MN) on the pig's forehead. Two paediatric rSO2 probes (SenSmart 8004CB, Nonin Medical, MN) were placed along a line between the lateral canthus of each eye and the medial portion of the bottom of the ear. For the purpose of these analyses, $\mathrm{rSO} 2$ values were used from the one of two probes that showed the greatest change in $\mathrm{rSO} 2$ pre-arrest to the end of the untreated VF period. Arterial blood gases (ABG) and reference blood samples were acquired through the femoral artery and analyzed using a Gem Premier 3000 device (Instrumentation Laboratory, Lexington, MA).

Data were continuously monitored during the study, including electrocardiographic monitoring, $\mathrm{EtCO}_{2}$, ICP, RAP, AoP, intrathoracic pressure using the BioPac data acquisition system (BioPac MP150; BioPac Systems Inc) and then stored and analyzed using the BioPac Acqknowledge 4.2 software.

\section{Experimental protocols}

\section{Study A:}

As outlined in Figure 2, VF was induced via direct current from a pacing wire placed in the right ventricle under fluoroscopy. After 7.75 minutes the CED was raised completely flat to the lowest elevation position (Figure 1). After 8 minutes of untreated VF, ACD CPR was performed with an automatic piston device (Caztek Engineering, St. Paul, MN). ACD CPR was performed 
at a rate of 100 compressions/minute, with a $50 \%$ duty cycle and depth of $22.5 \%$ anteroposterior chest diameter. Decompression was performed with a suction cup at an approximate force of $10 \mathrm{~kg}$. An ITD (ResQPOD-16, ZOLL Medical) was attached to the endotracheal tube at the initiation of CPR. Manual positive pressure ventilation was delivered with a tidal volume of $10 \mathrm{~mL} / \mathrm{kg}$ and a 30:2 compression:ventilation ratio, without oxygen to simulate basic life support (BLS) $[19,20]$ and to prime the cardio-cerebral circuit. After 2 minutes of BLS ACD+ITD CPR in the lowest CED position, ACD+ITD CPR was performed continuously with a 10:1 compression/ventilation ratio and the head and thorax were progressively elevated at a rate of $6 \mathrm{~cm} /$ minute over 2 minutes to the highest level of the CED was achieved. After 30 minutes of CPR in this highest CED position, 0.25 or $0.5 \mathrm{mg}$ of adrenaline was administered intravenously if the decompression phase arterial blood pressure was $20-30 \mathrm{mmHg}$, or $<20$ $\mathrm{mmHg}$, respectively. IV amiodarone $(25 \mathrm{mg})$ was administered at that time. Animals were then defibrillated with up to three $200 \mathrm{~J}$ biphasic shocks (X-series, ZOLL Medical). After ROSC, animals received isoflurane $(1.0 \%)$. The head and thorax were maintained at the highest CED level for 10 minutes before randomization into one of the following sequences for 5-minutes epochs: Flat, head up position (HUP), Flat, HUP (group 1) or HUP, Flat, HUP, Flat (group 2). Pigs completing the protocol were included in the study. They were then euthanized with an intravenous injection of $\mathrm{KCl}$.

Study B: After 6 minutes of untreated VF, automated C-CPR was performed in the supine and flat position, with the device shown in Figure 1, at 100 compressions per minute, a depth of $22 \%$ of the antero-postero-diameter, and a $50 \%$ duty cycle. Manual positive pressure ventilation was performed with room air with a 30:2 compression: ventilation ratio. After 5 minutes of CPR, medications, defibrillation, and euthanasia were delivered in a sequence and manner similar to Study A. If ROSC was not achieved, additional CPR was performed using ACD+ITD 
and pigs were defibrillated again. After ROSC, animals received isoflurane as in Study A. The head and thorax were maintained flat for 10 minutes before randomization to one of two 5minutes epoch sequences: Flat, HUP, Flat, HUP (group 1) or HUP, Flat, HUP, Flat (group 2). HUP was achieved with the device shown in Figure 1.

\section{Study outcomes}

The mean CerPP was the primary study endpoint. Secondary outcomes were mean arterial pressure, RAP, ICP, coronary perfusion pressure (CorPP), EtCO2 and rSO2. AoP, RAP, ICP, airway pressures, heart rate, $\mathrm{SpO} 2$ and $\mathrm{rSO} 2$ were measured and then averaged during the last minute of each 5-minutes epoch. CorPP was calculated as decompression phase, or diastolic, AoP minus RAP. CerPP was calculated as mean aortic pressure (MAP) minus ICP.

\section{Sample size}

We estimated that a sample size of 6 pigs would achieve $80 \%$ power to detect a mean difference of $10 \mathrm{mmHg}$ with an estimated standard deviation of 2 in CerPP between the HUP and Flat ACD+ITD groups, with significance level (alpha) of 0.05, using a two-sided t-test.

\section{Statistical analysis}

Data are expressed as mean \pm standard deviation. We fit multivariate analysis-of-variance (MANOVA) with the repeated measures appearing as dependent variables and time and head position entered as main effects. A first-order interaction involving time and head position was assessed for statistical significance. A paired t-test was also performed to compare the first two 5-minutes epoch interventions. All statistical tests were two-sided, and a p-value of $<0.05$ was required to reject the null hypothesis. P-values for all secondary outcomes were adjusted for 
multiple comparisons using the Bonferroni method. Statistical analysis was performed using the SPSS software (SPSS Statistics, Version 24.0. Armonk, NY: IBM Corp).

\section{RESULTS}

\section{Study A}

ROSC was achieved in 7 out of 9 pigs. After 29 minutes of CPR, the mean CerPP and CorPP were $36.2 \pm 24.4$ and $25.3 \pm 29.6 \mathrm{mmHg}$ for all 9 pigs. Arterial $\mathrm{pH}$ and lactates levels were $7.1 \pm 0.1$ and $7.5 \pm 1.4 \mathrm{mmol} / \mathrm{L}$. One pig had multiple broken ribs and a pneumothorax and did not achieve ROSC and one had refractory VF without ROSC. Additionally, one pig was profoundly hypotensive post-ROSC and died half way through the HUP/flat protocol.

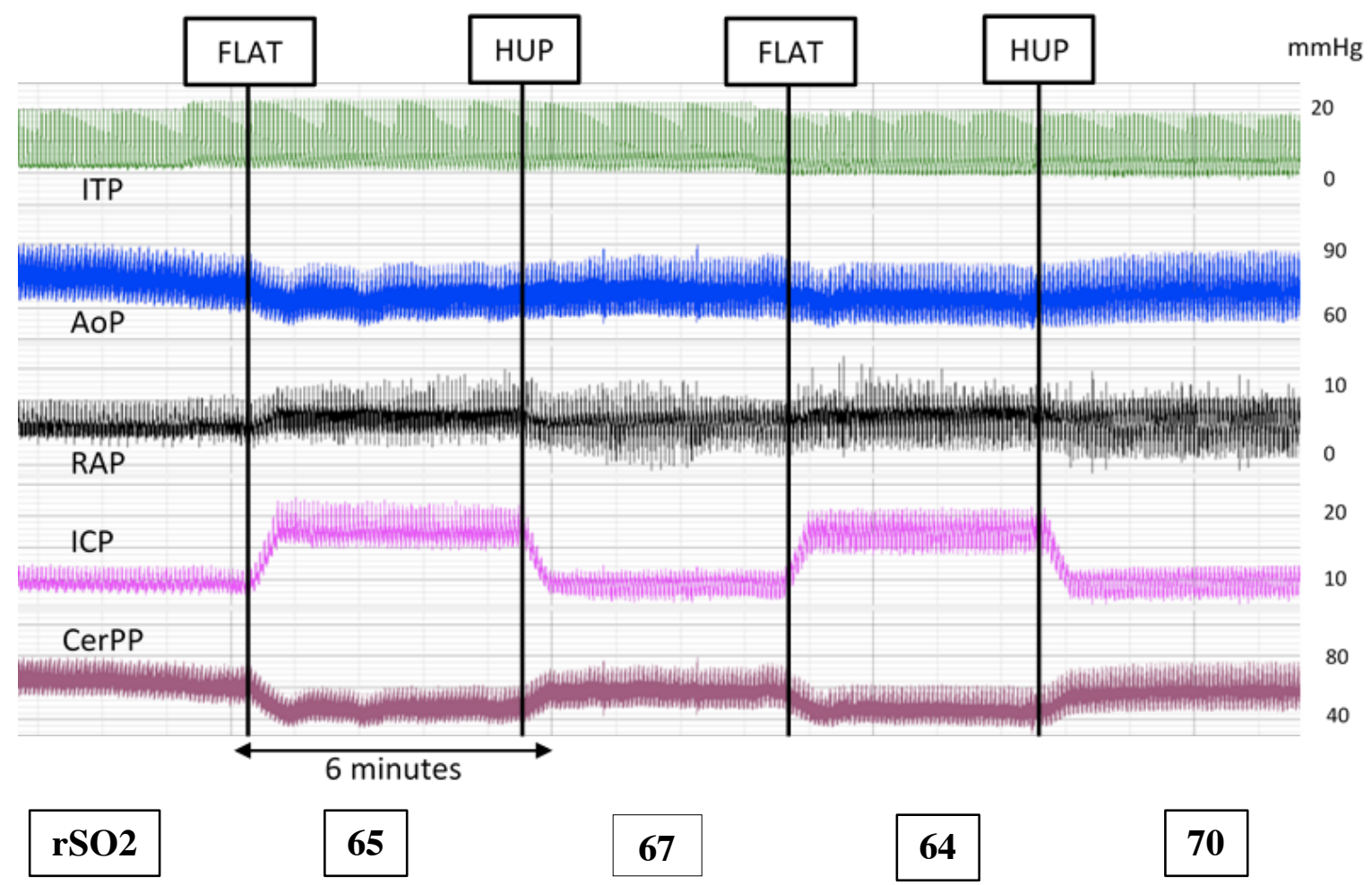

Figure 2: Representative haemodynamic tracings post-ROSC. ITP: Intrathoracic pressure, AoP: Aortic pressure, RAP: Right atrial pressure, ICP: Intracranial pressure, CerPP: Cerebral perfusion pressure. 
Hemodynamic variables, as well as arterial blood gas and serum lactate values for the 6 out of 9 pigs that survived the entire protocol, are shown in Table 1. After 29 minutes of ACD+ITD HUP CPR the mean CorPP and CerPP of the 6 survivors were $40.6 \pm 20.5 \mathrm{mmHg}$ and $50.5 \pm 15.6$ $\mathrm{mmHg}$, respectively. Arterial $\mathrm{pH}$ values were $7.1 \pm 0.1$ and lactate levels were $6.9 \pm 1.9 \mathrm{mmol} / \mathrm{L}$.
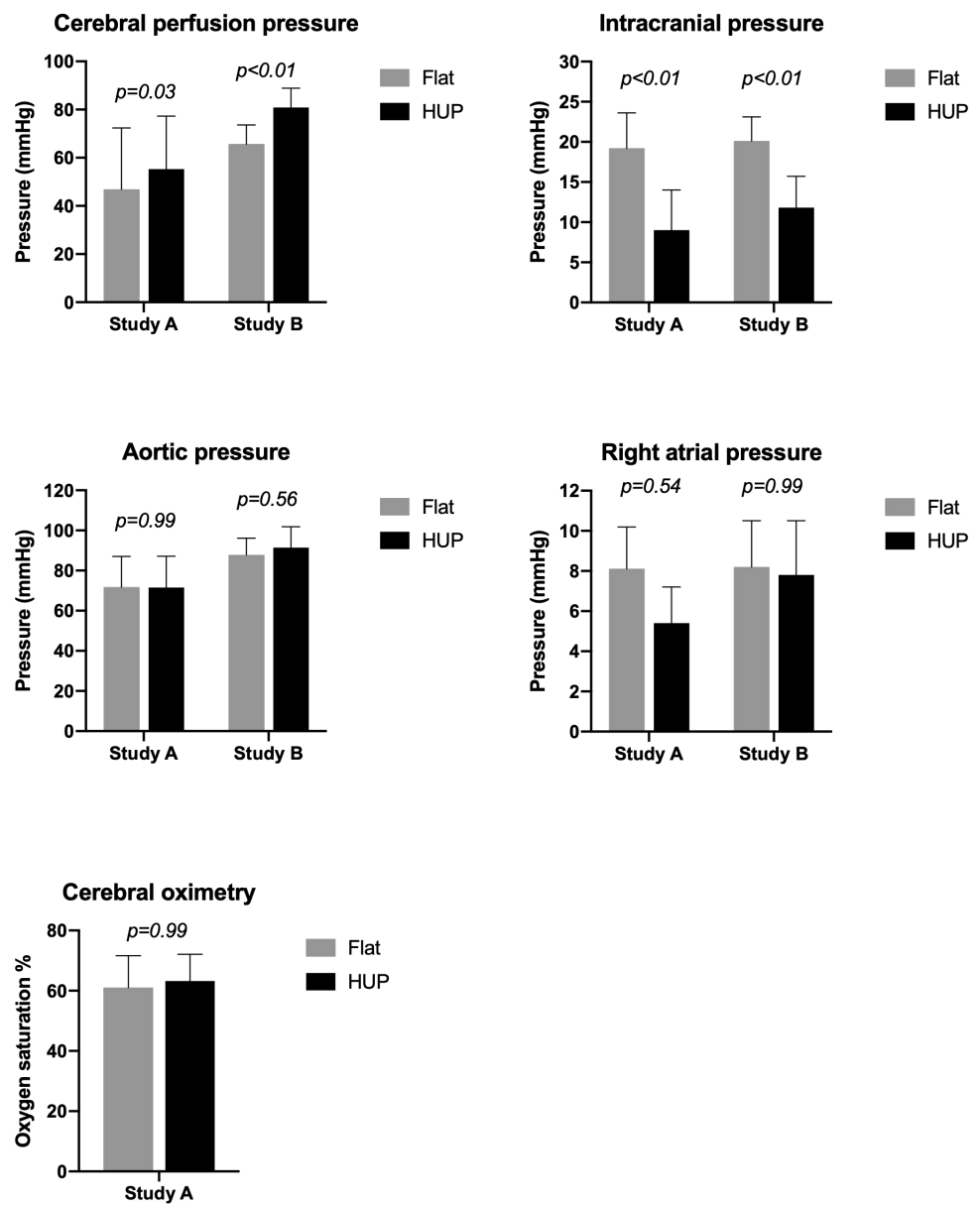

Figure 3: Main haemodynamic parameters and cerebral oximetry of HUP versus Flat for the whole post-ROSC period.

rSO2 values were measured continuously in all 9 pigs in study A. Prior to VF induction the mean $\mathrm{rSO} 2$ values were $73.9 \pm 3.1 \%$. These values decreased to $57.8 \pm 4.4 \%$ just prior to CPR. Over 30 minutes of CPR, rSO2 increased to a maximal level of $63.1 \pm 5.8 \%$ and were $59.1 \pm 6.4 \%$ just prior to defibrillation. 
After 29 minutes of CPR, rSO2 values were $61.8 \pm 5.1 \%$ in the $6 / 9$ pigs with a sustained ROSC versus $53.7 \pm 5.2 \%$ in the $3 / 9$ pigs without ROSC or sustained ROSC. Arterial lactate and $\mathrm{pH}$ values were $7.1 \pm 0.1$ and $6.9 \pm 1.9 \mathrm{mmol} / \mathrm{L}$ in the $6 / 9 \mathrm{pigs}$ with a sustained $\mathrm{ROSC}$ versus $7.2 \pm .02$ and $7.4 \pm 0.1 \mathrm{mmol} / \mathrm{L}$ in the $3 / 9$ pigs without ROSC or sustained ROSC, respectively.

\begin{tabular}{|c|c|c|c|c|c|}
\hline \multicolumn{3}{|l|}{ Protocol A } & \multicolumn{3}{|c|}{ All Interventions } \\
\hline & At baseline & $\begin{array}{l}\text { After } 29 \mathrm{~min} \\
\text { of CPR }\end{array}$ & Flat & HUP & $\mathbf{P}$ \\
\hline Intrathoracic pressure & $2.0(0.2)$ & $-2.4(1.3)$ & $1.8(0.6)$ & $1.5(0.3)$ & .99 \\
\hline Mean arterial pressure & $82.4(8.9)$ & $59.4(17.2)$ & $71.8(15.2)$ & $71.6(15.6)$ & .99 \\
\hline $\begin{array}{l}\text { Mean right atrial } \\
\text { pressure }\end{array}$ & $7.4(1.8)$ & $41.0(10.2)$ & $7.1(2.0)$ & $4.6(1.3)$ & .54 \\
\hline Intracranial pressure & $16.5(0.9)$ & $8.9(3.8)$ & $18.6(5.1)$ & $9.1(5.5)$ & $<.001$ \\
\hline $\begin{array}{l}\text { Cerebral perfusion } \\
\text { pressure }\end{array}$ & $65.9(8.4)$ & $50.5(15.6)$ & $53.2(19.1)$ & $62.5(19.9)$ & .004 \\
\hline $\begin{array}{l}\text { Coronary perfusion } \\
\text { pressure }\end{array}$ & $66.9(9.2)$ & $40.6(20.5)$ & $58.9(14.7)$ & $60.5(15.1)$ & .99 \\
\hline Cerebral oximetry & 74.8 (3.3) & $61.8(5.1)$ & $61.0(10.6)$ & $63.2(8.9)$ & .99 \\
\hline End-tidal $\mathrm{CO}_{2}$ & $39.4(3.0)$ & 34.3 (10.9) & $22.9(6.1)$ & $20.4(3.4)$ & .99 \\
\hline Oxygen saturation & $95.6(1.4)$ & $82.2(10.0)$ & $73.0(26.9)$ & $73.9(28.5)$ & .99 \\
\hline Heart rate & $92.3(12.1)$ & $100.0(0.0)$ & $148.4(28.0)$ & $148.4(16.3)$ & .99 \\
\hline Arterial $\mathrm{pH}$ & $7.46(0.03)$ & $7.10(0.08)$ & $7.09(0.13)$ & $7.09(0.14)$ & .99 \\
\hline Arterial lactate & $0.9(0.3)$ & $6.9(1.9)$ & $8.3(3.6)$ & $8.3(3.5)$ & .99 \\
\hline \multicolumn{2}{|l|}{ Protocol B } & & \multicolumn{3}{|c|}{ All Interventions } \\
\hline & At baseline & $\begin{array}{c}\text { After 6min of } \\
\text { CPR }\end{array}$ & Flat & HUP & $\mathbf{P}$ \\
\hline Intrathoracic pressure & $1.9(0.2)$ & $-0.8(0.4)$ & $1.8 \quad(0.4)$ & $1.4(0.7)$ & .99 \\
\hline Mean arterial pressure & $84.7(7.8)$ & $42.7(6.9)$ & $87.7 \quad(8.4)$ & $91.4(10.4)$ & .56 \\
\hline $\begin{array}{l}\text { Mean right atrial } \\
\text { pressure }\end{array}$ & $10.0(1.5)$ & $30.8(7.0)$ & $7.6 \quad(2.3)$ & 7.1 (2.6) & .99 \\
\hline Intracranial pressure & $19.1(1.9)$ & $25.3(4.3)$ & $19.7 \quad(3.0)$ & $11.0(4.3)$ & $<.001$ \\
\hline $\begin{array}{l}\text { Cerebral perfusion } \\
\text { pressure }\end{array}$ & $65.6(9.5)$ & $17.3(4.1)$ & $68.0 \quad(6.2)$ & $80.4(7.3)$ & $<.001$ \\
\hline $\begin{array}{l}\text { Coronary perfusion } \\
\text { pressure }\end{array}$ & $66.0(8.0)$ & $19.3(3.1)$ & $72.2 \quad(8.2)$ & $75.7(11.1)$ & .56 \\
\hline End-tidal $\mathrm{CO}_{2}$ & $37.6(1.7)$ & $4.6(3.2)$ & $35.8 \quad(7.5)$ & $31.4(8.9)$ & .99 \\
\hline Heart rate & $110.5(19.6)$ & $100.0(0.0)$ & 150.5 & $154.0(35.2)$ & .99 \\
\hline
\end{tabular}

Table 1: Haemodynamic measurements at baseline, at the end of CPR and in the post-ROSC period for the two studies. Values are mean (standard deviation). P values are comparing HUP vs Flat during post-ROSC for the whole experiment. All secondary outcome's P values are adjusted for multiple comparisons using the Bonferroni method.

Key outcomes are shown in Figures 3-5 and Table 1. For all 4 epochs studied, ICP values during HUP were $9.1 \pm 5.5 \mathrm{mmHg}$ and $18.6 \pm 5.1 \mathrm{mmHg}$ Flat $(\mathrm{p}<0.001)$ and CerPP was $62.5 \pm 19.9 \mathrm{mmHg}$ 
HUP and 53.2 $\pm 19.1 \mathrm{mmHg}$ Flat $(\mathrm{p}=0.004)$. As demonstrated in Figure 2, a representative pressure tracing from one animal, changes in body position resulted in rapid changes in ICP, RAP, CerPP, and rSO2 and no change in AoP. Randomization order did not alter the changes observed with the HUP and Flat positions. Specifically, with a MANOVA, no significant firstorder interaction involving time and head position was observed for CerPP $(P=0.46)$. CerPP was $9.3 \pm 7.0 \mathrm{mmHg}$ higher with HUP compared with Flat corresponding to a $17.4 \%$ higher CerPP levels ( $p=0.004$, Supplementary Table 2) but did not differ according to time of measurement $(P=0.96)$ (Figures 3 and 4 and Table 1). ICP values were $9.5 \pm 1.8 \mathrm{mmHg}$ lower with HUP $(P<0.001$, Supplementary Table 2$)$.

Arterial lactate, $\mathrm{rSO} 2, \mathrm{RAP}$ and $\mathrm{pH}$ and transcutaneous $\mathrm{SaO} 2$ values were not significantly altered by the position of the head and thorax post-ROSC when comparing values across all 4 epochs.

Outcomes were generally similar when data for the first two 5-minutes epoch interventions were analysed separately. Each time the head and thorax were elevated, RAP and ICP decreased, and CerPP increased, as shown in Figure 4. More specifically, for the first two 5minute epoch interventions, CerPP increased with HUP $7.4 \pm 7.3 \mathrm{mmHg}$ (a relative $14 \%$ change) $(\mathrm{p}=0.07)$, and ICP decreased $9.9 \pm 1.8 \mathrm{mmHg}$ (a relative 52\% decrease) $(\mathrm{p}<0.001)$. However, RAP values were significantly higher in the first two interventions (HUP/Flat) versus the second HUP/Flat sequence $(P=0.029)$, suggesting a real decrease in RAP over time. These changes were reproducible, both in terms of the rate and magnitude of change when comparing HUP versus Flat. In addition, rSO2 values were higher with HUP versus Flat in 5/6 pigs (for the last pig, values were equal) during epochs 1 and 2 (uncorrected $p=0.032$ ) but lost statistical 
significance with the Bonferonni correction. Two pigs with a sustained ROSC and low $\mathrm{SO}_{2}$ values throughout the experiment had severe lung injuries on necropsy.

Epinephrine was administered intravenously during the post-ROSC phase when the MAP was less than $55 \mathrm{mmHg}$. In the subgroup of 6 pigs with a sustained ROSC that completed the protocol, epinephrine was required in $2 / 6$ pigs to achieve ROSC and $3 / 6$ for at least some portion of the post-ROSC period. Use of epinephrine did not impact the changes in ICP, RAP, CerPP, MAP or rSO2 observed with a change in body position post-ROSC (data in Supplement).
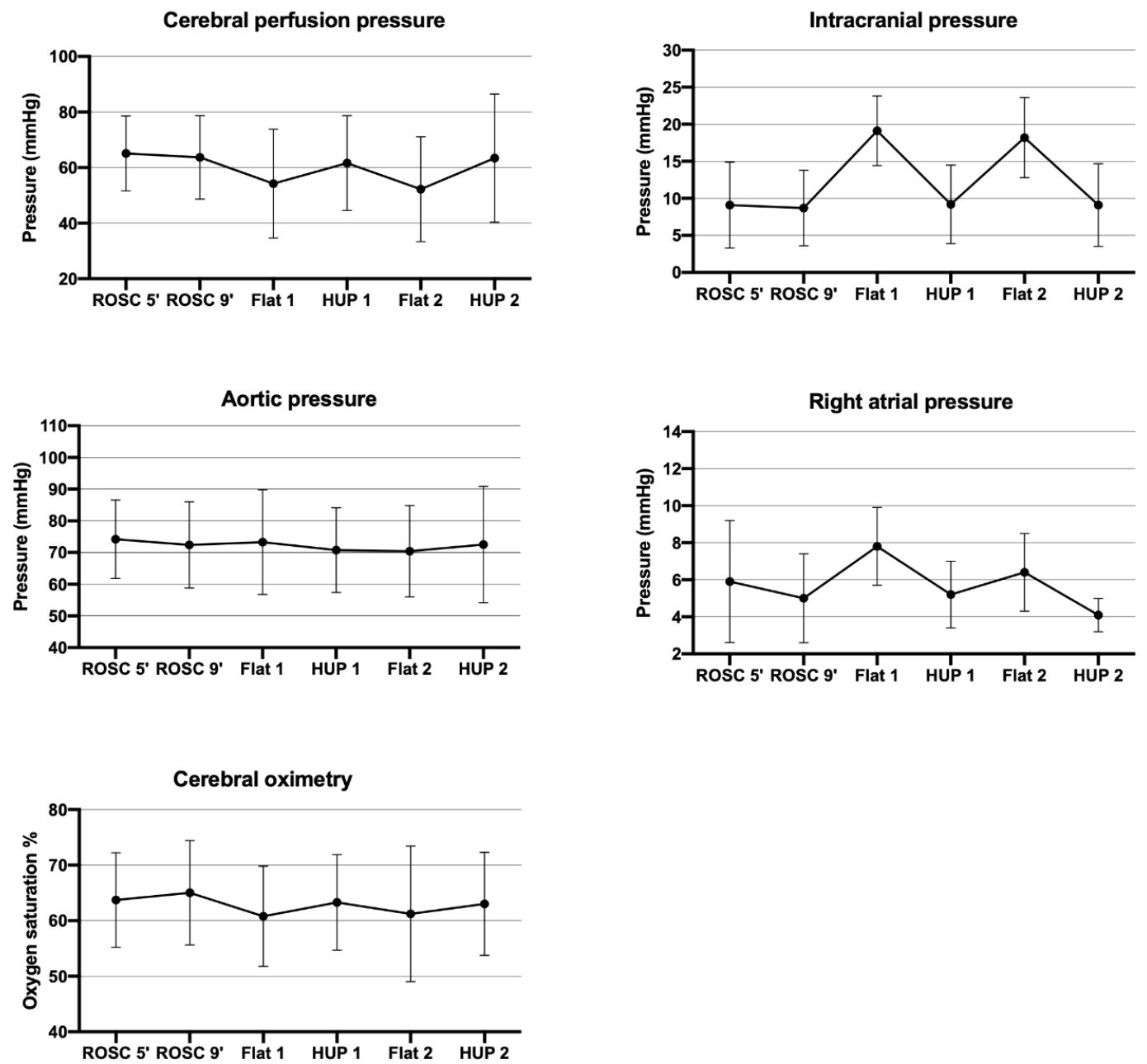

Figure 4: Evolution over time of the main haemodynamic parameters and of cerebral oximetry during the post-ROSC period in study A. 


\section{Study $B$}

Results from Protocol B, shown in Table 1 and Figures 3 and 5, were generally similar to those observed in Protocol A. ROSC was achieved in a total of 5/6 pigs after 6 minutes of untreated VF and 6 minutes of standard CPR. Additional CPR with ACD+ITD was needed in 1/6 pigs for achieving ROSC.

The CerPP, CorPP, and other key hemodynamic variables after 6 minutes of standard CPR and prior to defibrillation are shown in Table 1. After 6 minutes of CPR, the mean CorPP and CerPP were $19.3 \pm 3.1 \mathrm{mmHg}$ and $17.3 \pm 4.1 \mathrm{mmHg}$, respectively. Unfortunately, $\mathrm{rSO} 2$ values could not be obtained as part of Protocol B as sensors with adhesive were not available at the time of the experiments.
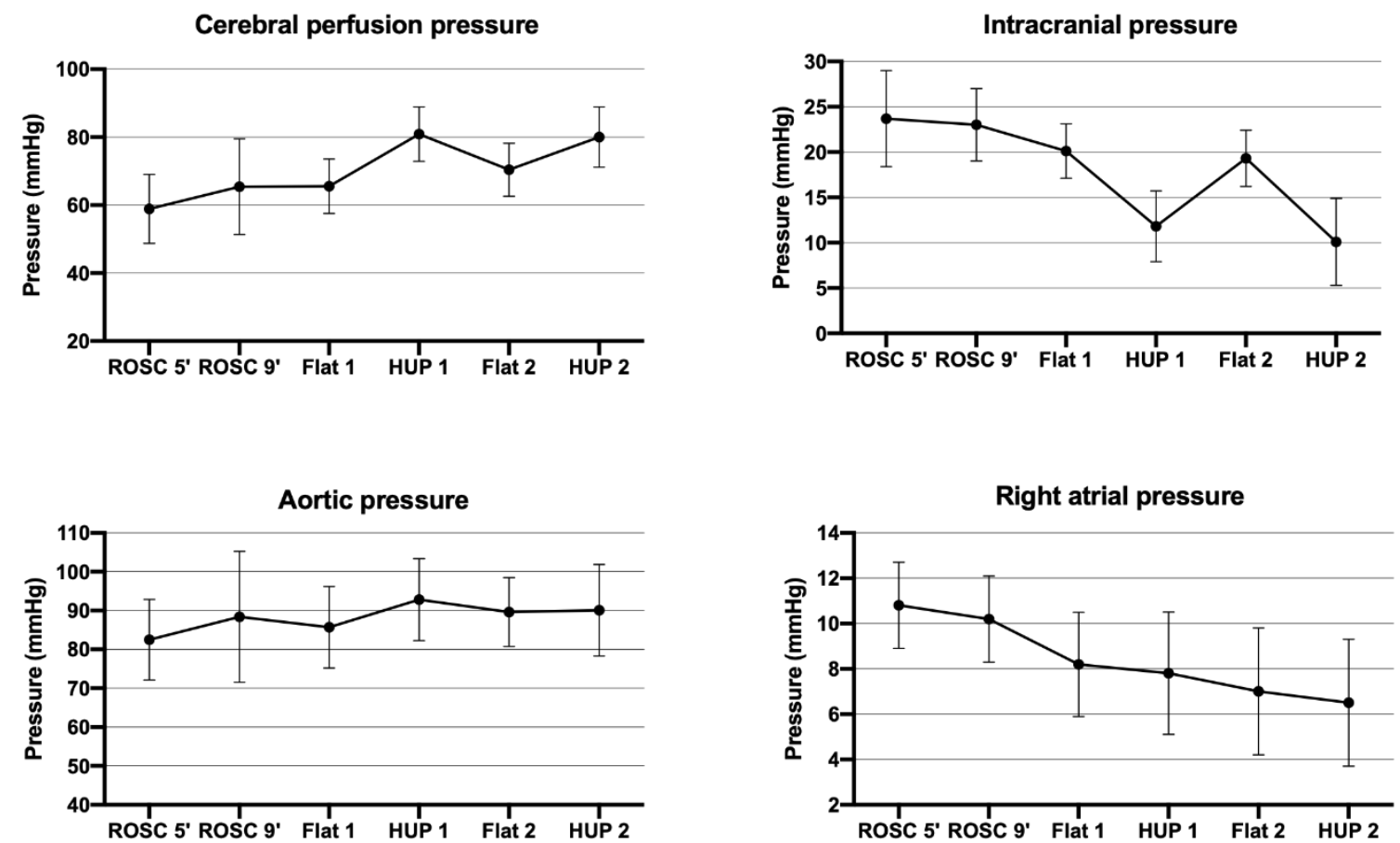

Figure 5: Evolution over time of the main haemodynamic parameters and of cerebral oximetry during the post-ROSC period in study B. 
Key outcomes are shown in Figures $3-5$ and table 1. For all 4 epochs studied ICP values during HUP were $11.0 \pm 4.3 \mathrm{mmHg}$ and $19.7 \pm 3.0 \mathrm{mmHg}$ Flat $(\mathrm{p}<0.001)$ and CerPP was $80.4 \pm 7.3 \mathrm{mmHg}$ HUP and $68.0 \pm 6.2 \mathrm{mmHg}$ Flat $(\mathrm{p}=0.001)$. In MANOVA, no significant firstorder interaction involving time and head position was observed for CerPP $(p=0.18)$. CerPP was $12.5 \pm 5.9 \mathrm{mmHg}$ higher with HUP compared with Flat, corresponding to $18.3 \%$ higher CerPP levels $(\mathrm{p}<0.001$, Supplementary table 3$)$ but did not differ according to time $(P=0.96)$ (Figure $3-5$ and Table 1). ICP values were $8.7 \pm 2.3 \mathrm{mmHg}$ lower with HUP $(\mathrm{p}<0.001)$.

Outcomes were similar when the data for the first two 5-minutes epoch interventions were analyse separately. Each time the head and thorax were elevated RAP and ICP decreased and CerPP increased, as shown in Figure 5. More specifically, for the first two 5-minutes epoch interventions, CerPP increased with HUP $15.3 \pm 6.2 \mathrm{mmHg}$ (a relative $23.4 \%$ increase) $(p=0.003$ ) and ICP decreased $8.3 \pm 2.4 \mathrm{mmHg}$ (a relative $41 \%$ decrease) $(\mathrm{p}<0.01)$. In contrast to Protocol A results, there were no differences in RAP depending on the time of intervention.

Epinephrine was required in 4/6 pigs to achieve ROSC and 1/6 for at least some portion of the post-ROSC period.

\section{DISCUSSION}

The goal of this study was to use an animal model of cardiac arrest to determine if elevation of the head and thorax after ROSC would be of hemodynamic benefit when compared with the conventional approach of leaving the body in the horizontal plane. Using a randomized controlled study design, we demonstrated that each time the head and thorax were elevated CerPP increased and ICP decreased, with two different methods of CPR and two different durations of untreated VF. MAP, on average, remained constant with a change in position. 
These new findings are supportive of a modest elevation the head and thorax after ROSC to lower ICP and improve CerPP, as long as the MAP is stable. The findings were consistent, for ACD+ITD CPR in the HUP position during resuscitation for 30 minutes prior to defibrillation and for C-CPR in the flat position for a shorter duration of VF and CPR. The overall observations are similar to what has been reported for the routine treatment of traumatic brain injury [21].

These investigations build upon recent studies demonstrating that controlled sequential elevation of the head and thorax during ACD+ITD CPR was synergistic, with near normalization of CerPP values after prolonged CPR and a 6-fold increase in neurologicallyintact survival in animals [19]. The natural question that arose from those studies was, should the head and heart remain elevated post ROSC? Our results demonstrate that CerPP increased by nearly $20 \%$ after ROSC after 30 minutes of ACD+ITD HUP CPR by maintaining HUP versus lowering the pigs to a flat position. The impact of gravity was profound, immediate, reproducible, and may be of significant clinical benefit. Each time the head and thorax were elevated $22 \mathrm{~cm}$ and $10 \mathrm{~cm}$, respectively, from the horizontal plane, ICP decreased on average $10 \mathrm{mmHg}$. In the setting of potential brain injury, a $10-\mathrm{mmHg}$ reduction in ICP may be clinically relevant [22]. Experimental models of cardiac arrest support the pathophysiological hypothesis of a worsening in vital organs during the reperfusion phase and extend over the first hours. Improving cerebral perfusion in the early post-ROSC phase could be of critical importance to limit reperfusion injuries.

This study was not designed to compare ACD+ITD CPR HUP versus C-CPR flat. However, it is noteworthy that after 8 minutes of untreated VF and 30 minutes of ACD+ITD HUP CPR the CerPP was $50.5 \pm 15.6 \mathrm{mmHg}$ and only $17.3 \pm 4.1 \mathrm{mmHg}$ after 6 minutes of untreated VF and 6 
minutes of C-CPR, consistently with previous reports [12,16]. Interestingly, post-ROSC CerPP values were approximately $20 \mathrm{mmHg}$ higher both HUP and flat after C-CPR in comparison with ACD+ITD HUP CPR. Further, in contrast to the ACD+ITD HUP CPR treatment group, there was no change in RAP with a change in body position post-ROSC in the C-CPR group. We speculate that these differences may reflect differences in autoregulation as well vascular and cardiac compliance as a result of the different CPR methods (e.g., more post-ROSC cerebral hyperaemia with C-CPR).

Although no adverse effects of HUP were observed in this study, there is a theoretical harm associated with HUP in the setting of significant hypotension, especially if the head is elevated too rapidly or too high. In patients with traumatic brain injury, $30^{\circ} \mathrm{HUP}$ is routinely used in the intensive care unit as it provides significant clinical benefit and improves clinical outcomes, but only when the MAP with HUP is adequate to pump blood 'uphill' [21].

This study has some limitations. First brain blood flow was not directly measured, nor were short term or long-term clinical outcomes. However, prior studies on head and thorax elevation during CPR have shown a close relationship between blood flow, CerPP and coronary perfusion pressure $[11,23]$. Our finding that post-ROSC HUP results in higher CerPP and lower ICP is therefore promising. Second, our study was powered to test the primary hypothesis but some of the differences in the secondary endpoints did not achieve statistical significance. The data demonstrating a rise in $\mathrm{rSO} 2$ when the head and thorax were elevated is intriguing but the study was underpowered to demonstrate this observation conclusively. This was likely due to the relatively limited effective sample size and inter-individual variability. Third, we used healthy pigs, without any co-morbidities commonly seen in human cardiac arrest. 


\section{CONCLUSION}

The results from this animal study demonstrate that head and thorax elevation post-ROSC significantly increases CerPP and lowers ICP. These preclinical data are a first step towards implementation of a new post-resuscitation intervention that could be synergistic with other head and thorax elevation manoeuvres during CPR and after ROSC to improve neurological survival, by decreasing the likelihood of brain injury. 
THÈSE SOUTENUE PAR : Hélène DUHEM

\section{L'ÉLÉVATION DE LA TÊTE ET DU TRONC AMÉLIORE LA PRESSION DE PERFUSION CÉRÉBRALE EN POST-ARRÊT CARDIAQUE}

\section{CONCLUSION :}

L'objectif de notre étude était de déterminer l'effet de la surélévation de la tête et du tronc après retour à une activité circulatoire spontanée (RACS) dans un modèle porcin d'arrêt cardiaque par fibrillation ventriculaire pris en charge avec deux techniques différentes de réanimation cardiopulmonaire (RCP). Le critère de jugement principal était la pression de perfusion cérébrale (CerPP) après RACS.

Notre principal résultat est que la CerPP post-RACS était significativement plus élevée en cas de surélévation de la tête et du tronc post-RACS qu'en cas de maintien en position à plat stricte $(+17 \%, \mathrm{p}=0.004$ et $+18 \%, \mathrm{p}=0.001$ respectivement dans les deux techniques de RCP). Par ailleurs, les pressions intracrâniennes étaient également réduites par la surélévation de la tête et du tronc. Ces bénéfices étaient indépendants de la durée de la fibrillation ventriculaire et de la méthode de RCP.

Les résultats de cette étude animale pré-clinique permettent d'envisager une nouvelle prise en charge des patients post arrêt cardiaque, potentiellement en synergie avec d'autres manœuvres d'élévation de la tête et du tronc en per-RCP, l'objectif étant d'améliorer la survie et le pronostic neurologique en diminuant la survenue de lésions cérébrales.

\section{VU ET PERMIS D'IMPRIMER}

Grenoble, le : $3 \log (b$

\section{LE DOYEN}

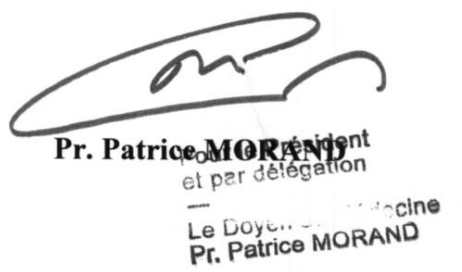

\section{LE PRÉSIDENT DE LA THÈSE}

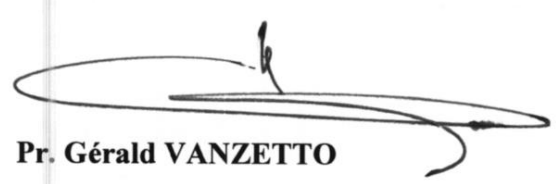




\section{REFERENCES}

[1] Alarcon JD, Rubiano AM, Okonkwo DO, et al. Elevation of the head during intensive care management in people with severe traumatic brain injury. Cochrane Database Syst Rev 2017;12:CD009986.

[2] Fan J-Y. Effect of backrest position on intracranial pressure and cerebral perfusion pressure in individuals with brain injury: a systematic review. J Neurosci Nurs J Am Assoc Neurosci Nurses 2004;36:278-88.

[3] Hoste EAJ, Roosens CDVK, Bracke S, et al. Acute effects of upright position on gas exchange in patients with acute respiratory distress syndrome. J Intensive Care Med 2005;20:43-9.

[4] Richard J-CM, Maggiore SM, Mancebo J, Lemaire F, Jonson B, Brochard L. Effects of vertical positioning on gas exchange and lung volumes in acute respiratory distress syndrome. Intensive Care Med 2006;32:1623-6.

[5] Mezidi M, Gu Guaggiore SM, Mancebo J, Lemaire F, Jonson B, Brochard L. Effects of position on respiratory mechanics in acute respiratory distress syndrome. Intensive Care Med 2019;45:292-4.

[6] Nava S, Larovere MT, Fanfulla F, Navalesi P, Delmastro M, Mortara A. Orthopnea and inspiratory effort in chronic heart failure patients. Respir Med 2003;97:647-53.

[7] Torchio R, Gulotta C, Greco-Lucchina P, et al. Orthopnea and tidal expiratory flow limitation in chronic heart failure. Chest 2006;130:472-9.

[8] Kramer B, Massie B, Topic N. Hemodynamic differences between supine and upright exercise in patients with congestive heart failure. Circulation 1982;66:820-5.

[9] Vitacca M, Scalvini S, Volterrani M, Paneroni M, Giordano A, Ambrosino N. Physiological and symptom effects of changing posture from sitting to supine, and vice versa, in stable chronic heart failure. Acta Cardiol 2016;71:543-8.

[10] Pepe PE, Scheppke KA, Antevy PM, et al. Confirming the Clinical Safety and Feasibility of a Bundled Methodology to Improve Cardiopulmonary Resuscitation Involving a HeadUp/Torso-Up Chest Compression Technique. Crit Care Med 2019;47:449-55.

[11] Moore JC, Segal N, Lick MC, et al. Head and thorax elevation during active compression decompression cardiopulmonary resuscitation with an impedance threshold device improves cerebral perfusion in a swine model of prolonged cardiac arrest. Resuscitation 2017;121:195-200.

[12] Ryu HH, Moore JC, Yannopoulos D, et al. The Effect of Head Up Cardiopulmonary Resuscitation on Cerebral and Systemic Hemodynamics. Resuscitation 2016;102:29-34.

[13] Lurie KG, Nemergut EC, Yannopoulos D, Sweeney M. The Physiology of Cardiopulmonary Resuscitation: Anesth Analg 2016;122:767-83.

[14] Petersen LG, Petersen JCG, Andresen M, Secher NH, Juhler M. Postural influence on intracranial and cerebral perfusion pressure in ambulatory neurosurgical patients. Am J Physiol Regul Integr Comp Physiol 2016;310:100-4.

[15] Tasker RC. Intracranial pressure: influence of head-of-bed elevation, and beyond. Pediatr Crit Care Med J Soc Crit Care Med World Fed Pediatr Intensive Crit Care Soc 2012;13:116-7. 
[16] Moore JC, Holley J, Segal N, et al. Consistent head up cardiopulmonary resuscitation haemodynamics are observed across porcine and human cadaver translational models. Resuscitation 2018;132:133-9.

[17] Debaty G, Shin SD, Metzger A, et al. Tilting for perfusion: Head-up position during cardiopulmonary resuscitation improves brain flow in a porcine model of cardiac arrest. Resuscitation 2015;87:38-43.

[18] Nolan JP, Soar J, Cariou A, et al. European Resuscitation Council and European Society of Intensive Care Medicine Guidelines for Post-resuscitation Care 2015: Section 5 of the European Resuscitation Council Guidelines for Resuscitation 2015. Resuscitation 2015;95:202-22.

[19] Rojas-Salvador C, Moore JC, Salverda B, Lick M, Debaty G, Lurie KG. Effect of controlled sequential elevation timing of the head and thorax during cardiopulmonary resuscitation on cerebral perfusion pressures in a porcine model of cardiac arrest. Resuscitation 2020;149:162-9.

[20] Kleinman ME, Brennan EE, Goldberger ZD, et al. Part 5: Adult Basic Life Support and Cardiopulmonary Resuscitation Quality: 2015 American Heart Association Guidelines Update for Cardiopulmonary Resuscitation and Emergency Cardiovascular Care. Circulation 2015;132:414-35.

[21] Brain Trauma Foundation, American Association of Neurological Surgeons, Congress of Neurological Surgeons, Joint Section on Neurotrauma and Critical Care, AANS/CNS, Bratton SL, Chestnut RM, et al. Guidelines for the management of severe traumatic brain injury. VI. Indications for intracranial pressure monitoring. J Neurotrauma 2007;24:3744.

[22] Abraham P, Rennert RC, Gabel BC, et al. ICP management in patients suffering from traumatic brain injury: a systematic review of randomized controlled trials. Acta Neurochir (Wien) 2017;159:2279-87.

[23] Debaty G, Moore J, Duhem H, et al. Relationship between hemodynamic parameters and cerebral blood flow during cardiopulmonary resuscitation. Resuscitation. Accepted manuscript. 


\section{Supplementary material}

\begin{tabular}{|c|c|c|c|c|c|c|c|c|}
\hline \multicolumn{9}{|l|}{ Protocol A } \\
\hline \multirow{3}{*}{$\begin{array}{l}\text { Intrathoracic pressure Epinephrine } \\
\text { Intrathoracic pressure No Epinephrine }\end{array}$} & \multicolumn{2}{|c|}{ At Baseline } & \multicolumn{2}{|c|}{ After 30min of CPR } & \multicolumn{2}{|c|}{ Flat } & \multicolumn{2}{|c|}{ HUP } \\
\hline & 2.6 & $(0.9)$ & -2.3 & $(0.8)$ & 1.5 & $(0.8)$ & 1.6 & $(0.2)$ \\
\hline & 2.0 & $(0.3)$ & -2.8 & $(1.5)$ & 1.8 & $(0.3)$ & 1.4 & $(0.3)$ \\
\hline Mean arterial pressure Epinephrine & 78.7 & $(10.2)$ & 40.8 & $(13.1)$ & 54.4 & $(21.5)$ & 53.2 & $(19.5)$ \\
\hline Mean arterial pressure No Epinephrine & 84.4 & $(4.8)$ & 73.5 & $(6.4)$ & 78.8 & $(13.8)$ & 80.8 & $(12.0)$ \\
\hline Mean right atrial pressure Epinephrine & 6.7 & $(1.7)$ & 36.3 & $(16.0)$ & 7.9 & $(2.8)$ & 4.8 & $(1.7)$ \\
\hline Mean right atrial pressure No Epinephrine & 8.1 & $(1.2)$ & 39.4 & $(5.2)$ & 7.0 & $(0.1)$ & 5.2 & $(1.1)$ \\
\hline Intracranial pressure Epinephrine & 16.2 & $(0.8)$ & 6.0 & $(1.5)$ & 20.1 & $(5.9)$ & 9.7 & (6.6) \\
\hline Intracranial pressure No Epinephrine & 17.1 & $(0.6)$ & 12.3 & $(2.1)$ & 17.1 & $(0.1)$ & 8.1 & $(0.4)$ \\
\hline Cerebral perfusion pressure Epinephrine & 62.5 & $(10.1)$ & 34.8 & $(14.4)$ & 34.3 & $(25.0)$ & 43.5 & $(23.2)$ \\
\hline Cerebral perfusion pressure No Epinephrine & 67.2 & $(4.2)$ & 61.2 & $(8.4)$ & 61.7 & $(13.7)$ & 72.8 & $(12.4)$ \\
\hline Coronary perfusion pressure Epinephrine & 64.1 & $(10.7)$ & 21.0 & $(8.2)$ & 46.2 & $(21.9)$ & 42.8 & $(17.2)$ \\
\hline Coronary perfusion pressure No Epinephrine & 68.2 & $(4.7)$ & 59.3 & (7.3) & 72.2 & $(13.9)$ & 70.1 & $(11.8)$ \\
\hline Cerebral oximetry Epinephrine & 76.0 & $(3.4)$ & 57.8 & $(6.6)$ & 51.5 & $(7.7)$ & 55.5 & $(9.2)$ \\
\hline Cerebral oximetry No Epinephrine & 72.3 & $(0.9)$ & 63.7 & $(2.6)$ & 69.2 & $(4.1)$ & 68.7 & $(2.2)$ \\
\hline End-tidal $\mathrm{CO}_{2}$ Epinephrine & 36.3 & $(7.7)$ & 23.0 & $(4.0)$ & 12.6 & $(7.5)$ & 16.1 & $(7.0)$ \\
\hline End-tidal $\mathrm{CO}_{2}$ No Epinephrine & 38.5 & $(1.7)$ & 44.7 & $(0.8)$ & 29.0 & $(0.6)$ & 20.9 & $(3.6)$ \\
\hline Heart rate Epinephrine & 94.9 & $(14.9)$ & 100.0 & $(0.0)$ & 121.4 & $(59.1)$ & 129.6 & $(45.8)$ \\
\hline Heart rate No Epinephrine & 81.8 & $(5.4)$ & 100.0 & $(0.0)$ & 146.6 & $(14.9)$ & 141.8 & $(15.7)$ \\
\hline Arterial pH Epinephrine & 7.46 & $(0.02)$ & 7.11 & $(0.08)$ & 6.96 & $(0.03)$ & 6.96 & $(0.01)$ \\
\hline Arterial pH No Epinephrine & 7.46 & $(0.03)$ & 7.11 & $(0.00)$ & 7.23 & $(0.04)$ & 7.22 & $(0.02)$ \\
\hline Arterial lactate Epinephrine & 0.9 & $(0.2)$ & 7.5 & $(1.6)$ & 11.8 & $(1.0)$ & 10.0 & (2.6) \\
\hline Arterial lactate No Epinephrine & 1.0 & $(0.4)$ & 5.5 & $(0.0)$ & 4.8 & $(0.3)$ & 4.7 & $(0.4)$ \\
\hline
\end{tabular}

Supplementary Table 1: Comparison of the main haemodynamic parameters between the pigs that received epinephrine and the pigs that didn't in study A and B. 


\begin{tabular}{|c|c|c|c|c|c|}
\hline \multirow{2}{*}{ Protocol A } & \multicolumn{5}{|c|}{ All Interventions } \\
\hline & $\begin{array}{c}\text { Absolute } \\
\text { Value }\end{array}$ & $\begin{array}{c}\text { Mean } \\
\text { difference }\end{array}$ & & $\%$ & $\mathbf{P}^{*}$ \\
\hline Intrathoracic pressure Flat & 1.8 & & & & \\
\hline Intrathoracic pressure HUP & 1.5 & -0.3 & $(0.7)$ & -18.6 & .99 \\
\hline Mean arterial pressure Flat & 71.8 & & & & \\
\hline Mean arterial pressure HUP & 71.6 & -0.2 & $(6.9)$ & -0.3 & .99 \\
\hline Mean right atrial pressure Flat & 7.1 & & & & \\
\hline Mean right atrial pressure HUP & 4.6 & -2.4 & $(2.3)$ & -34.4 & .54 \\
\hline Intracranial pressure Flat & 18.6 & & & & \\
\hline Intracranial pressure HUP & 9.1 & -9.5 & $(1.8)$ & -51.0 & $<.001$ \\
\hline Cerebral perfusion pressure Flat & 53.2 & & & & \\
\hline Cerebral perfusion pressure HUP & 62.5 & 9.3 & $(7.0)$ & 17.4 & .004 \\
\hline Coronary perfusion pressure Flat & 58.9 & & & & \\
\hline Coronary perfusion pressure HUP & 60.5 & 1.6 & $(6.9)$ & 2.6 & .99 \\
\hline Cerebral oximetry Flat & 61.0 & & & & \\
\hline Cerebral oximetry HUP & 63.2 & 2.2 & $(4.3)$ & 3.6 & .99 \\
\hline End-tidal $\mathrm{CO}_{2}$ Flat & 22.9 & & & & \\
\hline End-tidal $\mathrm{CO}_{2} \mathrm{HUP}$ & 20.4 & -2.5 & $(8.9)$ & -11.1 & .99 \\
\hline Heart rate Flat & 148.4 & & & & \\
\hline Heart rate HUP & 148.4 & 0.0 & (17.3) & 0.0 & .99 \\
\hline Arterial pH Flat & 7.09 & & & & \\
\hline Arterial pH HUP & 7.09 & 0.01 & $(0.02)$ & -0.01 & .99 \\
\hline Arterial lactate Flat & 8.3 & 0 & $(0,1)$ & $0 \cap 1$ & 9 \\
\hline Arterial lactate HUP & 8.3 & 0.0 & $(0.4)$ & -0.01 & .99 \\
\hline
\end{tabular}

Supplementary Table 2: Difference in absolute values shown as mean (standard deviation) and percentage change between HUP and Flat position for the main haemodynamic parameters in study A. 


\begin{tabular}{|c|c|c|c|c|c|}
\hline \multirow[t]{2}{*}{ Protocol B } & \multicolumn{5}{|c|}{ All Interventions } \\
\hline & $\begin{array}{l}\text { Absolute } \\
\text { Values }\end{array}$ & $\begin{array}{c}\text { Mean } \\
\text { differences }\end{array}$ & & $\%$ & $\mathbf{P}$ \\
\hline Intrathoracic pressure FLAT & 1.8 & 01 & (0 9) & 265 & 09 \\
\hline Intrathoracic pressure HUP & 1.4 & -0.4 & (0.9) & -20.0 & .95 \\
\hline Mean arterial pressure FLAT & 87.7 & 37 & (6 8) & 43 & 56 \\
\hline Mean arterial pressure HUP & 91.4 & 3.1 & (b.8) & 4.3 & .56 \\
\hline Mean right atrial pressure FLAT & 7.6 & 01 & (1) & 50 & (00 \\
\hline Mean right atrial pressure HUP & 7.1 & -0.4 & $(1.9)$ & -5.6 & .99 \\
\hline Intracranial pressure FLAT & 19.7 & 87 & (2) 3 ) & 143 & $<001$ \\
\hline Intracranial pressure HUP & 11.0 & -0.1 & $(2.3)$ & -44.3 & 8.001 \\
\hline Cerebral perfusion pressure FLAT & 68.0 & 125 & $(50)$ & 183 & $<001$ \\
\hline Cerebral perfusion pressure HUP & 80.4 & 12.5 & (0.5) & 10.0 & .001 \\
\hline Coronary perfusion pressure FLAT & 72.2 & 2 & 67 & 10 & 50 \\
\hline Coronary perfusion pressure HUP & 75.7 & 3.5 & (b.7) & 4.9 & .56 \\
\hline End-tidal $\mathrm{CO}_{2} \mathrm{FLAT}$ & 35.8 & -45 & (111) & -124 & 99 \\
\hline End-tidal $\mathrm{CO}_{2} \mathrm{HUP}$ & 31.4 & -4.5 & $(11.1)$ & -12.4 & .99 \\
\hline Heart rate FLAT & 150.5 & 35 & $\left(\begin{array}{ll}8 & 1\end{array}\right)$ & 23 & 09 \\
\hline Heart rate HUP & 154.0 & 3.0 & $(0.1)$ & 2.3 & .99 \\
\hline
\end{tabular}

Supplementary Table 3: Difference in absolute values shown as mean (standard deviation) and percentage change between HUP and Flat position for the main haemodynamic parameters in study B. 


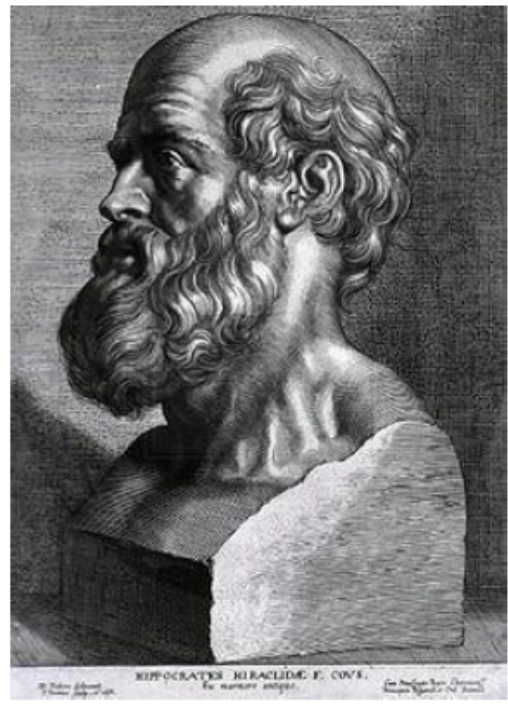

\section{SERMENT D'HIPPOCRATE}

En présence des Mâtres de cette Faculté, de mes chers condisciples et devant l'effigie d'HIPPOCRATE,

Je promets et je jure d'être fidèle aux lois de l'honneur et de la probité dans l'exercice de la Médecine.

Je donnerai mes soins gratuitement à l'indigent et n'exigerai jamais un salaire au dessus de mon travail. Je ne participerai à aucun partage clandestin d'honoraires.

Admis dans l'intimité des maisons, mes yeux n'y verront pas ce qui s'y passe; ma langue taira les secrets qui me seront confiés et mon état ne servira pas à corrompre les mours, ni à favoriser le crime.

Je ne permettrai pas que des considérations de religion, de nation, de race, de parti ou de classe sociale viennent s'interposer entre mon devoir et mon patient.

Je garderai le respect absolu de la vie humaine.

Même sous la menace, je n'admettrai pas de faire usage de mes connaissances médicales contre les lois de l'humanité.

Respectueux et reconnaissant envers mes Maîtres, je rendrai à leurs enfants l'instruction que j'ai reçue de leurs pères.

Que les hommes m'accordent leur estime si je suis fidèle à mes promesses.

Que je sois couvert d'opprobre et méprisé de mes confrères si j'y manque. 